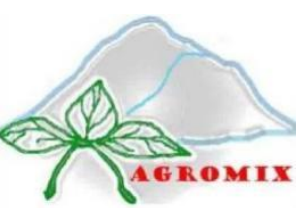

\title{
AGROMIX
}

Jurnal IImiah Fakultas Pertanian, Universitas Yudharta Pasuruan pISSN (Print): 2085-241X; elSSN (Online): 2599-3003

Website: https://jurnal.yudharta.ac.id/v2/index.php/agromix

\section{Persepsi peternak tentang teknologi asap cair (liquid smoke) tempurung kelapa di kelompok ternak satwa mandiri Kabupaten Kediri}

\author{
Perception of farmers in coconut shell liquid smoke technology in Satwa Mandiri group of Kediri Regency
}

Yunita Ninsi Saputri ${ }^{1^{*}}$, Wahyu Windari ${ }^{1}$, Nurlaili ${ }^{1}$

${ }^{1}$ Program Studi Penyuluhan Peternakan dan Kesrawan, Polbangtan Malang, Indonesia

*Email korespondensi: yninsi@gmail.com

\section{Article History}

Received : August 11, 2020

Accepted : February 28, 2021

Published : March 30, 2021

\section{Keyword}

Liquid smoke; factors;

farmer perception

\section{ABSTRACT}

This study aims to (1) determine the perceptions of farmers about coconut shell liquid smoke technology and (2) determine the factors that influence it. The research method used a descriptive quantitative approach with a survey method. Sampling using saturated samples with some 34 people. Data analysis was performed with descriptive data analysis and multiple linear regression analysis to measure the $X$ factor (age, business experience, business income, cosmopolitan expectations, and interests) to factor $Y$ (Perception). The results of the study showed that farmers with positive/good perceptions of coconut shell liquid smoke technology were $53 \%$, while farmers who had negative perceptions were $47 \%$. The analysis results obtained multiple linear regression equation $Y=(4.179)+(-0,119) X 1+(0.208) X 2+$ $(0.114) X 3+(1,475) X 4+(0.297) X 5+(0.490) X 6$ with $R$ of 0.547 and $R 2$ equal to 0.859 . The results of the model summary explain the summary of the model consisting of multiple correlation values $(R)$, 0.927 . This shows that there is a high relationship between the variable $x$ (age, business experience, business income, cosmopolitan, hopes, and interests) and the farmers' perceptions of coconut shell liquid smoke technology. The t-test results show the t-count value of the cosmopolitan factor (4.142) and the factor of interest (2.114)>t-table (2.051) at the significance level of a $5 \%$. The factors that influence farmers' perceptions of liquid smoke technology are cosmopolitan and interest. In general, breeders have good perceptions of liquid smoke technology, so that the application of liquid smoke technology in animal husbandry can be applied repeatedly to suppress environmental pollution due to the odor generated by laying chicken manure.

\section{Riwayat Artikel}

Dikirim : 11 Agustus 2020

Disetujui : 28 Pebruari 2021

Diterbitkan : 30 Maret 2021

\section{Kata Kunci}

Asap cair; faktor-faktor; persepsi peternak

\section{ABSTRAK}

Penelitian ini bertujuan untuk (1) mengetahui persepsi peternak tentang teknologi asap cair tempurung kelapa dan (2) mengetahui faktor-faktor yang mempengaruhinya. Metode penelitian menggunakan pendekatan kuantitatif deskriptif dengan metode survey. Pengambilan sampel menggunakan sampel jenuh dengan jumlah 34 orang. Analisis data dilakukan dengan analisis data diskriptif dan analisis regresi linier berganda untuk mengukur faktor $X$ (umur, pengalaman usaha, pendapatan usaha, kosmopolitan harapan dan minat) terhadap faktor $Y$ (Persepsi). Hasil kajian menunjukkan bahwa peternak yang berpersepsi positif/baik pada teknologi asap cair tempurung kelapa sebesar $53 \%$ sedangkan peternak yang berpersepsi negatif sebesar $47 \%$. Dari hasil analisis diperoleh persamaan regresi linier berganda $Y$ $=(4,179)+(-0,119) X 1+(0,208) X 2+(0,114) X 3+(1,475) X 4+(0,297) X 5+(0,490) X 6$ dengan $R$ sebesar 0,547 dan $\mathrm{R} 2$ sebesar 0,859 . Hasil dari model summary menjelaskan tentang ringkasan model yang terdiri dari nilai korelasi berganda $(R), 0,927$. Hal ini menunjukkan bahwa terjadi hubungan yang tinggi antara variabel $\mathrm{x}$ (umur, pengalaman usaha, pendapatan usaha, kosmopolitan, harapan dan minat) dengan persepsi peternak dalam teknologi asap cair tempurung kelapa. Hasil uji t menunjukkan nilai t-hitung faktor kosmopolitan $(4,142)$ dan faktor minat $(2,114)>$ t-tabel $(2,051)$ pada taraf signifikansi a $5 \%$. Faktor-faktor yang mempengaruhi persepsi peternak dalam teknologi asap cair yaitu faktor kosmopolitan dan minat. Secara umum peternak berpersepsi baik pada teknologi asap cair, sehingga penerapan teknologi asap cair pada usaha peternakan dapat diterapkan secara berulang untuk menekan pencemaran lingkungan akibat bau yang ditimbulkan oleh kotoran ayam ras petelur.

Sitasi: Saputri, Y. N., Windari, W., \& Nurlaili, N. (2021). Persepsi peternak tentang teknologi asap cair (liquid smoke) tempurung kelapa di kelompok ternak satwa mandiri Kabupaten Kediri. Agromix, 12(1), 17-24. https://doi.org/10.35891/agx.v12i1.2206 


\section{PENDAHULUAN}

Produk peternakan merupakan salah satu sektor yang penting dalam pemenuhan kebutuhan manusia akan pangan khususnya pemenuhan kebutuhan akan protein hewani. Sesuai standar nasional, konsumsi protein per hari per kapita ditetapkan 55 gram yang terdiri atas $80 \%$ protein nabati dan $20 \%$ protein hewani (Sudarmono, 2007). Pemenuhan protein hewani dapat diperoleh dengan mengkonsumsi daging dan telur. Perkembangan usaha peternakan ayam ras yang pesat didorong oleh peningkatan konsumsi telur oleh masyarakat. Pada tahun 2018, populasi ayam ras petelur di Jawa Timur sebesar 47,463,380 dari jumlah total populasi se-Indonesia sebanyak 181,752,456 dengan tingkat pertumbuhan dari tahun 2017 sebesar 1,20\% (Pusat Data dan Informasi Pertanian, 2018). Meningkatnya usaha peternakan ayam ras petelur tentunya memiliki dampak terhadap lingkungan sekitar, terutama bau yang ditimbulkan oleh kotoran ayam. Pengelolaan peternakan ayam petelur yang tidak baik terutama limbah ternak akan menimbulkan keresahan dan penilaian masyarakat yang buruk bagi peternakan tersebut.

Kelompok Ternak Satwa Mandiri merupakan kelompok ternak ayam ras petelur yang berada di Kabupaten Kediri Provinsi Jawa Timur. Kelompok Ternak Satwa Mandiri dibentuk sebagai wadah berbagi informasi antar peternak ayam ras petelur yang ada di Kabupaten Kediri. Kelompok dipilih karena aktif dalam melakukan berbagai kegiatan seperti pertemuan rutin setiap bulannya dan satu-satunya kelompok ternak yang ada di kabupaten Kediri dengan usaha anggota yang bergerak di bidang peternakan ayam ras petelur. Jumlah kepemilikan ternak per anggota antara 800-15.000 ekor. Pada umumnya, peternak melakukan kegiatan budidaya ayam petelur dekat dengan rumah peternak. Lokasi yang dekat mempermudah peternak dalam pengawasan dan manajemen pemeliharaan ayam petelur. Namun, lokasi yang dekat dengan pemukiman warga memiliki dampak terhadap lingkungan sekitar berupa bau tidak sedap terutama ketika musim penghujan.

Penggunaan teknologi asap cair berbahan dasar tempurung kelapa dapat membantu dalam pengurangan bau pada peternakan ayam karena mengandung senyawa-senyawa yang berbau asap seperti karbonil, furan, fenol, siklopenten, benzene dan lainnya. Asap cair merupakan pengembunan asap hasil penguraian senyawa-senyawa organik yang terdapat dalam kayu sewaktu proses pirolisis (Aziz dkk., 2011). Bahan dasar asap cair tempurung kelapa mudah diperoleh karena Kabupaten Kediri merupakan salah satu kabupaten yang menyumbang limbah pertanian tempurung kelapa. Berdasarkan hasil identifikasi wilayah dan pengumpulan data melalui observasi dan wawancara bahwasanya Kelompok Ternak Satwa Mandiri sebelumnya belum mengetahui tentang teknologi asap cair tempurung kelapa yang dapat dijadikan sebagai alternatif pengurang bau pada peternakan ayam ras petelur. Pemahaman peternak terhadap suatu inovasi teknologi tentu membutuhkan kesiapan mental sehingga dapat mengambil sebuah keputusan untuk melakukan adopsi teknologi yang bermanfaat dan dapat diterapkan oleh peternak melalui proses persepsi. Penelitian ini bertujuan untuk mengetahui persepsi peternak dalam teknologi asap cair tempurung kelapa dan mengetahui faktor-faktor yang mempengaruhi persepsi peternak mengenai teknologi asap cair tempurung kelapa.

\section{METODE}

Penelitian ini dilaksanakan di Kecamatan Ringinrejo Kabupaten Kediri, dengan responden yaitu Kelompok Ternak Satwa Mandiri Kabupaten Kediri. Pelaksanaan penelitian dimulai pada bulan Mei sampai dengan Juli 2020. Metode yang digunakan yaitu pendekatan kuantitatif deskriptif dengan menjelaskan serta menggambarkan secara umum tentang bagaimana persepsi peternak dalam teknologi asap cair tempurung kelapa dan regresi linier berganda untuk mengukur faktor yang mempengaruhi persepsi. Pelaksanaan penelitian berupa pengumpulan data dan informasi dari responden menggunakan metode survey dengan alat berupa kuesioner.

\section{Populasi dan sampel}

Menurut Sugiyono (2015) sampel adalah bagian dari jumlah dan karakteristik yang dimiliki oleh populasi tersebut. Sampel yang diambil harus betul-betul representatif (mewakili). Pengambilan sampel yang digunakan adalah sampel jenuh dimana keseluruhan populasi dijadikan sampel, sehingga menghasilkan responden sejumlah 34 orang.

\section{Variabel penelitian}

Pada penelitian ini faktor-faktor yang diduga mempengaruhi persepsi peternak dalam teknologi asap cair tempurung kelapa sebagai pengurang bau kotoran ayam ras petelur yaitu: umur (X1), pengalaman usaha (X2), pendapatan usaha (X3) kosmopolitan (X4) dan harapan (X5) minat (X6). Pada penelitian ini variabel dependen (Y) merupakan persepsi peternak dimana indikator persepsi terdiri dari penyerapan terhadap ransang, pemahaman, dan penilaian.

\section{Instrumen dan teknik uji instrumen}

Instrumen yang digunakan merupakan kuesioner yang berisi pernyataan berkenaan dengan fakta yang dialami responden dan dibuat dalam bentuk checklist. Mengukur suatu variabel diperlukan alat ukur yang biasa disebut instrumen (Sappaile, 2007). Skala pengukuran yang digunakan untuk adalah skala likert. Pengujian instrumen 
dilakukan dengan uji validasi isi dan butir menggunakan kesepakatan tiga orang ahli (expert judgement). Teknik analisis validitas dan reabilitas menggunakan formula aiken.

\section{Analisa data}

Analisis deskriptif kuantitatif digunakan untuk menjelaskan hasil data likert yang diterapkan terkait data persepsi peternak dalam teknologi asap cair. Persepsi peternak dianalisis menggunakan Skor T Selanjutnya untuk menganalisis faktor-faktor yang mempengaruhi persepsi digunakan metode kuantitatif yaitu analisis regresi linier berganda menggunakan software SPSS 20. Rancangan model matematis yang terbentuk dalam regresi linier berganda sebagai berikut:

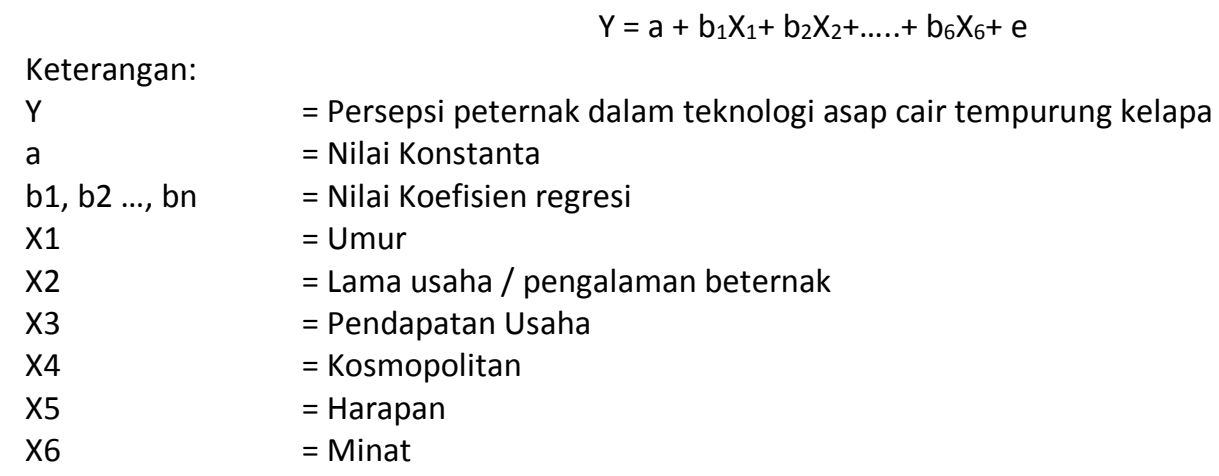

\section{HASIL DAN PEMBAHASAN}

\section{Karakteristik responden}

Kelompok Ternak Satwa Mandiri dibentuk sebagai wadah berbagi informasi antar peternak ayam ras petelur yang ada di Kabupaten Kediri. Anggota Kelompok Ternak Satwa Mandiri tersebar di empat kecamatan yaitu kecamatan Ringinrejo, Kandat, Kras dan Mojo. Kelompok ini aktif dalam melakukan berbagai kegiatan seperti diadakannya pertemuan rutin setiap bulannya. Berdasarkan hasil pengambilan data melalui ipw dan survei pada Kelompok Ternak Satwa Mandiri Kabupaten Kediri diperoleh karakteristik responden yang meliputi: Umur, Pengalaman, Pendapatan Usaha, tingkat kosmopolitan, tingkat pengharapan dan tingkat minat.

\section{Umur}

Umur responden pada penelitian bervariasi mulai usai termuda yaitu 30 tahun dan usia tertua 50 tahun. Umur merupakan salah satu faktor yang mempengaruhi perilaku responden dalam pengambilan keputusan. Hasil karakteristik responden menunjukkan bahwa umur responden berada pada kriteria produktif. Menurut UndangUndang Republik Indonesia No.13 Tahun 2003 tentang Ketenagakerjaan, (2003) bahwa orang yang memiliki usia produktif adalah > 15 sampai dengan < 64 tahun. Umur yang produktif bisa bekerja secara maksimal dan memberikan hasil yang lebih banyak di bandingkan dengan usia yang kurang produktif (Herawati \& Sasana, 2013).

Tabel 1. Karakteristik responden berdasarkan umur

\begin{tabular}{cccc}
\hline No & Umur (tahun) & Jumlah (orang) & Persentase (\%) \\
\hline 1 & $30-35$ & 6 & $18 \%$ \\
2 & $36-40$ & 11 & $32 \%$ \\
3 & $41-45$ & 12 & $35 \%$ \\
4 & $46-50$ & 5 & $15 \%$ \\
\hline
\end{tabular}

\section{Pengalaman usaha}

Pengalaman dalam beternak merupakan salah satu faktor yang dapat mempengaruhi perilaku responden dalam pengambilan keputusan (Pablo, 1994). Menurut Suharyat (2009) terbentuknya sikap positif terhadap suatu objek cenderung ditentukan oleh pengalaman individu pada suatu objek. Pengalaman usaha yang dilakukan oleh seseorang dapat dijadikan tolak ukur keberhasilan dalam melakukan suatu usaha sekaligus sebagai acuan seorang peternak mampu mengatasi sebuah permasalahan dan mengambil keputusan untuk memajukan usahanya. Senada dengan Lestari, dkk. (2009) yang menyatakan bahwa pengambilan keputusan dan tindakan akan suatu masalah tergantung pada lamanya seseorang dalam menjalankan usahanya.

Tabel 2. Karakteristik responden berdasarkan pengalaman usaha

\begin{tabular}{cccc}
\hline No & Pengalaman usaha (tahun) & Jumlah (orang) & Persentase (\%) \\
\hline 1 & $<10$ & 19 & $58 \%$ \\
2 & $10-12$ & 10 & $30 \%$ \\
3 & $>12$ & 4 & $12 \%$ \\
\hline
\end{tabular}




\section{Pendapatan usaha}

Pendapatan usaha merupakan salah satu faktor yang dapat mempengaruhi perilaku responden (sikap / pendapat) dalam pengambilan sebuah keputusan (Singh \& Verma, 2017; Wang dkk., 2014). Pendapatan usaha pada penelitian ini merupakan jumlah seluruh penghasilan yang diperoleh responden selama satu bulan. Pendapatan usaha dapat dijadikan penentu seorang peternak dalam mengambil suatu tindakan pada usahanya. Sesuai dengan pendapat Yusnita (2010) tingkat pendapatan yang tinggi seseorang akan dapat melakukan tindakan apapun untuk keberhasilan usahanya.

Tabel 3. Karakteristik responden berdasarkan pendapatan usaha

\begin{tabular}{cccc}
\hline No & Pendapatan usaha (Rp) & Jumlah (orang) & Persentase (\%) \\
\hline 1 & $<1.750 .000$ & 6 & $18 \%$ \\
2 & $1.750 .000-2.500 .000$ & 7 & $21 \%$ \\
3 & $2.550 .000-3250.000$ & 9 & $26 \%$ \\
4 & $>3.250 .000$ & 12 & $35 \%$ \\
\hline
\end{tabular}

\section{Kosmopolitan}

Kosmopolitan merupakan intensitas peternak dalam melakukan hubungan atau kontak dengan berbagai sumber informasi. Informasi yang diperoleh berasal dari berbagai sumber seperti media elektronik, media cetak, media sosial, informasi antar anggota kelompok, informasi dari penyuluh, dan lain-lain.

Tabel 4. Tingkat Kosmopolitan Responden

\begin{tabular}{ccccc}
\hline No. & Tingkat Kosmopolitan & Nilai & Responden (N) & Persentase (\%) \\
\hline 1. & Sangat Tinggi & $18-20$ & 17 & 50 \\
2. & Tinggi & $15-17$ & 7 & 24 \\
3. & Sedang & $12-14$ & 6 & 21 \\
4. & Rendah & $9-11$ & 2 & 6 \\
5. & Sangat Rendah & $5-8$ & 0 & 0 \\
\hline
\end{tabular}

Sumber: Data Primer yang diolah, 2020

Berdasarkan tabel 4 tingkat kosmopolitan responden dibagi menjadi lima kategori yaitu sangat tinggi, tinggi, sedang, rendah dan sangat rendah. Kosmopolitan memiliki hubungan dengan seberapa tinggi tingkat informasi yang diperoleh / didapatkan oleh responden dari luar. Tingkat kosmopolitan yang sangat tinggi disebabkan oleh keingintahuan responden yang tinggi untuk mencari informasi. Sejalan dengan Azwar dkk., (2016). Tingginya tingkat kosmopolitan tersebut mengindikasikan bahwa petani sudah memiliki keterbukaan dan keinginan untuk mencari informasi tentang suatu teknologi di luar dari lingkungan sosialnya dengan harapan adanya perubahan pengetahuan, sikap dan keterampilan yang dimiliki.

\section{Harapan}

Harapan merupakan salah satu faktor yang mempengaruhi persepsi. Harapan merupakan bentuk dari kepercayaan akan sesuatu keinginan yang akan didapatkan. Adapun hasil kajian mengenai harapan responden disajikan pada diagram berikut ini.

Tabel 5. Tingkat harapan responden

\begin{tabular}{ccccc}
\hline No. & Tingkat Harapan & Nilai & Responden (N) & Persentase (\%) \\
\hline 1. & Sangat Tinggi & $13,7-16$ & 1 & 3 \\
2. & Tinggi & $11,3-13,6$ & 16 & 47 \\
3. & Sedang & $8,9-11,2$ & 17 & 50 \\
4. & Rendah & $6,5-8,8$ & 0 & 0 \\
5. & Sangat Rendah & $4-6,4$ & 0 & 0 \\
\hline
\end{tabular}

Tingkat harapan dibagi menjadi lima tingkatan yaitu sangat tinggi, tinggi, sedang, rendang, dan sangat rendah. Tabel 5. menunjukkan bahwa tingkat harapan responden pada penggunaan asap cair tempurung kelapa mayoritas berada pada tingkatan sedang dan tinggi. Peternak yang memiliki harapan yang tinggi merupakan peternak yang berpersepsi positif pada penggunaan asap cair tempurung kelapa. Hal ini sesuai dengan pendapat Arifin dkk., (2017) yang menyatakan bahwa responden cenderung berpersespi positif karena memiliki harapan yang tinggi akan suatu obyek.

\section{Minat}

Minat merupakan kesadaran seseorang akan suatu obyek. Minat pada penelitian ini merupakan ketertarikan responden akan asap cair. Adapun hasil kajian mengenai minat responden disajikan pada diagram berikut ini. 
Tabel 6. Tingkat minat responden

\begin{tabular}{ccccc}
\hline No. & Tingkat Harapan & Nilai & Responden $(\mathrm{N})$ & Persentase $(\%)$ \\
\hline 1. & Sangat Tinggi & $18-20$ & 14 & 41 \\
2. & Tinggi & $15-17$ & 13 & 38 \\
3. & Sedang & $12-14$ & 6 & 18 \\
4. & Rendah & $9-11$ & 1 & 3 \\
5. & Sangat Rendah & $5-8$ & 0 & 0 \\
\hline
\end{tabular}

Tingkat minat dibagi menjadi lima tingkatan yaitu sangat tinggi, tinggi, sedang, rendang, dan sangat rendah. Tabel 6. menunjukkan bahwa tingkat minat responden pada penggunaan asap cair tempurung kelapa mayoritas berada pada tingkatan sangat tinggi dan tinggi. Hendayana (2014) menyatakan bahwa Minat setiap orang terhadap suatu obyek bervariasi tergantung pada penilaian orang tersebut terhadap obyek yang dihadapinya. Karena itu persepsi yang diberikan seseorang juga akan berbeda. Dapat diketahui bahwa peternak berdasarkan tingkat minat memiliki kategori tinggi, hal ini menunjukkan bahwa peternak memiliki penilaian yang positif akan teknologi asap cair tempurung kelapa.

\section{Persepsi peternak dalam teknologi asap cair tempurung kelapa}

Pengukuran persepsi dilakukan untuk mengetahui seberapa besar penerimaan dan penilaian peternak mengenai asap cair tempurung kelapa. Adapun hasil dari analisis persepsi dapat dilihat pada Tabel 7

Tabel 7 Persepsi peternak dalam teknologi asap cair tempurung kelapa

\begin{tabular}{cccc}
\hline Kategori & Interval & Jumlah responden & Persentase (\%) \\
\hline Positif & T skor $>50,0$ & 18 & $53 \%$ \\
Negatif & T skor $<50,0$ & 16 & $47 \%$ \\
\hline
\end{tabular}

Berdasarkan tabel di atas dapat diketahui bahwa responden dengan T skor > 50,0 sejumlah 18 orang (53\%) berpersepsi positif sedangkan responden dengan T skor < 50,0 sejumlah 16 orang (47\%) berpersepsi negatif. Hal ini menunjukkan bahwa peternak dominan berpersepsi baik pada penggunaan asap cair sebagai pengurang bau pada kotoran ayam petelur. Persepsi merupakan bagian dari sikap seseorang dalam melakukan penilaian terhadap suatu obyek. Menurut Kubro dkk. (2019) Sikap peternak bernilai positif pada suatu program merupakan peternak yang sudah mengetahui dan memiliki pengalaman pribadi akan suatu program sedangkan sikap peternak yang bernilai negatif yaitu peternak yang belum memiliki pengalaman pada suatu program. Sehingga Persepsi peternak dominan positif menunjukkan bahwa peternak sebelumnya sudah mengetahui tentang asap cair dari tempurung kelapa. Selain itu peternak beranggapan bahwa asap cair dari tempurung kelapa memiliki manfaat pada usahanya oleh karena itu peternak merasa tertarik pada teknologi tersebut. Keadaan peternak yang beranggapan bahwa asap cair yang dibuat dari bahan organik dan mudah diperoleh di sekitar lingkungan usahanya menarik minat mereka untuk mengetahui lebih lanjut mengenai teknologi tersebut. sedangkan Peternak yang berpersepsi negatif merupakan peternak yang sebelumnya belum mengetahui secara baik akan teknologi asap cair dari tempurung kelapa. Sehingga dibutuhkan pemahaman yang lebih untuk mengubah persepsi seseorang. Hal ini sesuai dengan pendapat Yanti dkk. (2017) Persepsi seseorang terhadap suatu obyek akan positif apabila sesuai dengan kebutuhannya, sebaliknya akan negatif apabila bertentangan dengan kebutuhan orang tersebut.

\section{Faktor-faktor yang mempengaruhi persepsi peternak}

Analisis regresi linier berganda menghasilkan persamaan regresi berikut ini: $Y=(4,179)+(-0,119) X_{1}+(0,208) X_{2}+(0,114) X_{3}+(1,475) X_{4}+(0,297) X_{5}+(0,490) X_{6}$

Hasil dari model summary menjelaskan tentang ringkasan model yang terdiri dari nilai korelasi berganda ( $R$ ), 0,927 . $\mathrm{Hal}$ ini menunjukkan bahwa terjadi hubungan yang tinggi antara variabel $\mathrm{x}$ (umur, pengalaman usaha, pendapatan usaha, kosmopolitan, harapan dan minat) dengan persepsi peternak dalam teknologi asap cair tempurung kelapa. Selanjutnya diketahui bahwa nilai $R^{2}$ ( $R$ square) sebesar 0,859 atau sebesar $85,9 \%$. Hal ini menunjukkan bahwa persentase pengaruh variabel umur, pengalaman usaha, pendapatan usaha, kosmopolitan, pengharapan, dan minat terhadap persepsi peternak dalam teknologi asap cair dari tempurung kelapa sebesar 85,9\%. Hal ini berarti 85,9\% persepsi peternak dipengaruhi oleh variabel umur, pengalaman usaha, pendapatan usaha, kosmopolitan, pengharapan, dan minat, sedangkan sisanya yaitu 14,1\% dipengaruhi oleh variabel lainnya yang tidak diteliti dalam penelitian ini. 
Tabel 8. Hasil uji t parsial dengan regresi linear berganda

\begin{tabular}{|c|c|c|c|c|c|}
\hline Variabel & $\begin{array}{c}\text { Unstandardized } \\
\text { B }\end{array}$ & $t_{\text {hitung }}$ & $t_{\text {tabel }}$ & Sig. & Keterangan \\
\hline & 4,179 & & & & \\
\hline Umur & $-0,119$ & $-0,760$ & & 0,454 & Tidak signifikan \\
\hline Pengalaman & 0,208 & 0,858 & & 0,398 & Tidak signifikan \\
\hline Pendapatan Usaha & 0,114 & 0,972 & 2,051 & 0,340 & Tidak signifikan \\
\hline Kosmopolitan & 1,475 & 4,142 & & 0,000 & signifikan \\
\hline Harapan & 0,297 & 0,967 & & 0,342 & Tidak signifikan \\
\hline Minat & 0,490 & 2,114 & & 0,044 & signifikan \\
\hline
\end{tabular}

Keterangan: Signifikan (alpha 0,05)

Hasil uji t menunjukkan faktor yang mempengaruhi persepsi peternak adalah variabel kosmopolitan dan minat. Hal ini dibuktikan dengan adanya nilai t-hitung faktor kosmopolitan $(4,142)$ dan faktor minat $(2,114)>t$-tabel $(2,051)$ pada taraf signifikansi $\alpha 5 \%$.

\section{Faktor kosmopolitan}

Kosmopolitan merupakan intensitas peternak dalam melakukan hubungan atau kontak dengan berbagai sumber informasi. Selain itu kosmopolitan dapat diartikan suatu kondisi dimana peternak dapat terbuka atau membuka dirinya terhadap dunia luar sehingga dapat menerima informasi yang dapat memunculkan ide untuk pembaharuan. Informasi yang dimiliki peternak tentang teknologi baru menjadi faktor membentuk persepsi individu terhadap teknologi yang diterima (Meijer dkk., 2015). Pada analisis uji T parsial diketahui bahwa kosmopolitan berpengaruh secara signifikan $($ sig<0,05) terhadap persepsi peternak dalam teknologi asap cair dari tempurung kelapa sebagai pengurang bau pada kotoran ayam ras petelur. Hal ini menunjukkan bahwa semakin tinggi tingkat kosmopolitan seseorang maka semakin positif persepsinya terhadap suatu teknologi. Peternak yang memiliki kosmopolitan tinggi dapat memperoleh informasi yang lebih banyak daripada peternak dengan tingkat kosmopolitan yang rendah. Selain itu peternak dengan tingkat kosmopolitan tinggi dapat membawa inovasi baru untuk mengembangkan usahanya menjadi lebih baik karena banyak berinteraksi dengan orang-orang luar yang dapat menambah informasi seputar usahanya. Hasil penelitian ini sejalan dengan Azwar, dkk. (2016) yang menyatakan bahwa responden yang memiliki tingkat kosmopolitan tinggi lebih banyak memperoleh berbagai sumber informasi.

\section{Faktor minat}

Minat merupakan bentuk psikologis dari ketertarikan peternak pada asap cair tempurung kelapa. Menurut Butler (1987) minat / interest merupakan salah satu faktor dari dalam individu yang dapat mempengaruhi persepsi. Pada penelitian ini umur berpengaruh secara signifikan terhadap persepsi $(s i g<0,05)$ dilihat dari uji T parsial. Hal ini menunjukkan bahwa semakin tinggi minat seseorang maka semakin positif persepsi terhadap teknologi. Minat yang tinggi disebabkan karena teknologi yang ditawarkan menimbulkan ketertarikan. Peternak tertarik karena teknologi asap cair memiliki manfaat untuk mengurangi bau pada usaha peternakan dan berasal dari bahan organik yaitu tempurung kelapa yang mudah diperoleh di lingkungan sekitar.

\section{Faktor yang tidak mempengaruhi persepsi}

Berdasarkan hasil uji t faktor yang tidak mempengaruhi persepsi meliputi variabel umur, pengalaman, pendapatan usaha, dan harapan. Diketahui bahwa umur responden $100 \%$ berada pada kriteria umur yang produktif (30-50 tahun) sehingga tidak ada perbedaan persepsi walaupun terdapat perbedaan pada penggolongan umur. Hal ini sesuai dengan penelitian Imamsyah dkk. (2019) yang menyatakan bahwa umur tidak mempengaruhi persepsi dikarenakan 91,67\% umur peternak berada pada kriteria produktif. Selain itu tinggi rendahnya umur tidak dapat menentukan persepsi seseorang. Tidak menutup kemungkinan bahwa usia yang lebih tua memiliki persepsi negatif begitu juga sebaliknya.

Pengalaman usaha peternak pada penelitian ini merupakan lama usaha yang telah dilakukan oleh peternak dalam melakukan budidaya ayam ras petelur. Pengalaman usaha menjadi salah satu pengaruh dalam keberhasilan suatu usaha. Pengalaman usaha dapat membantu peternak dalam keberhasilan usahanya dikarenakan semakin lama usahanya maka semakin terbiasa untuk menghadapi resiko. Pengalaman usaha tidak mempengaruhi persepsi peternak dalam teknologi asap cair tempurung kelapa, karena pengalaman usaha tani peternak beragam. Hal ini menunjukkan bahwa semakin lamanya pengalaman usaha peternak tidak dapat menentukan persepsinya. Hal tersebut sejalan dengan penelitian Azwar, dkk. (2016) dan yang menyatakan bahwa pengalaman usaha tani seseorang tidak menjadi penentu persepsi seseorang. Peternak masih memiliki keinginan untuk mengetahui teknologi-teknologi yang dapat meningkatkan keberhasilan usaha taninya. Namun Faktor pengalaman yang tidak berpengaruh pada persepsi pada penelitian ini berbeda pada penelitian sebelumnya seperti yang dinyatakan oleh Amalyadi dkk., (2019) dan yang menyatakan bahwa persepsi peternak pada fermentasi gedebok pisang dipengaruhi oleh karakteristik individu meliputi umur, pendidikan, dan pengalaman/lama beternak. Perbedaan hasil pada penelitian ini kemungkinan disebabkan karena perbedaan sasaran dan obyek yang diteliti. 
Dapat dikatakan mempengaruhi persepsi dimana jika semakin tinggi pendapatan usaha maka persepsi peternak semakin baik. Namun pada penelitian ini peternak memiliki pendapatan usaha yang beragam, tidak hanya peternak yang memiliki pendapatan usaha yang tinggi yang memiliki persepsi baik pada penggunaan teknologi asap cair. Peternak dengan pendapatan rendah juga memiliki persepsi yang baik pada teknologi asap cair, sehingga faktor pendapatan usaha pada penelitian ini tidak mempengaruhi persepsi. Banyak sedikitnya pendapatan usaha tidak menentukan peternak dalam mempersepsikan teknologi asap cair tempurung kelapa. Hal ini sesuai dengan pendapat Fitriana (2015) yang menyatakan bahwa pendapatan usaha tidak berpengaruh signifikan terhadap persepsi konsumen dikarenakan produk yang ditawarkan terjangkau.

Harapan menyangkut tanggapan peternak mengenai keuntungan penggunaan asap cair dan teknologi asap cair dapat menyelesaikan permasalahan mengenai pencemaran lingkungan. Dapat dikatakan mempengaruhi persepsi jika semakin tinggi harapan maka persepsi peternak semakin baik. Namun pada penelitian ini menunjukkan bahwa semakin tinggi pengharapan seseorang tidak dapat menentukan persepsinya. Peternak memiliki pengharapan yang tinggi pada teknologi asap cair dari tempurung kelapa untuk menghilangkan bau pada kotoran ayam petelur dan memberikan keuntungan pada usahanya. Peternak berpendapat bahwa asap cair dapat mengurangi bau pada peternakan ayam ras petelur jika diaplikasikan secara teratur. Asap cair dari tempurung kelapa sendiri mengandung senyawa-senyawa seperti fenol yang dapat menurunkan bau pada peternakan ayam ras petelur dikarenakan fenol memiliki bau yang khas. Hal ini sesuai dengan pendapat Assidiq dkk. (2018) yang menyatakan bahwa tempurung kelapa menghasilkan asap cair yang berbau sangat menyengat dan berwarna cokelat pekat.

\section{KESIMPULAN}

Persepsi peternak satwa mandiri pada teknologi asap cair dari tempurung kelapa sebesar 53\% positif menunjukkan bahwa peternak sebelumnya sudah mengetahui manfaat tentang asap cair dari tempurung kelapa sedangkan $47 \%$ berpersepsi negatif karena belum mengetahui manfaat tentang asap cair tempurung kelapa. Faktor kosmopolitan dan faktor minat berpengaruh signifikan terhadap persepsi peternak dalam teknologi asap cari tempurung kelapa sebagai pengurang bau pada kotoran ayam ras petelur sedangkan faktor umur, pengalaman usaha dan pendapatan usaha tidak berpengaruh signifikan terhadap persepsi.

\section{DAFTAR PUSTAKA}

Amalyadi, R., Ismulhadi, I., \& Windari, W. (2019). Persepsi peternak tentang pemanfaatan pakan fermentasi gedebog pisang untuk sapi potong di Desa Tambaksari Kecamatan Purwodadi Kabupaten Pasuruan. Jurnal Penyuluhan Pembangunan, 1(2), 35-39.

Arifin, H. S., Fuady, I., \& Kuswarno, E. (2017). Analisis faktor yang mempengaruhi persepsi mahasiswa terhadap keberadaan perda syariah di Kota Serang. Jurnal Penelitian Komonikasi dan Opini Publik, 21(1), 88-101.

Assidiq, F., Rosahdi, T. D., \& Viera, B. V. El. (2018). Pemanfaatan asap cair tempurung kelapa dalam pengawetan daging sapi. Al-Kimiya, 5(1), 34-41. https://doi.org/10.15575/ak.v5i1.3723

Aziz, T., Indraman, M. F., \& Alawiyah, U. (2011). Pemanfaatan tempurung kelapa dan tempurung sawit untuk pembuatan asap cair sebagai penghilang bau pada lateks dengan metode pirolisis. Jurnal Teknik Kimia, 17(8), 41-48.

Azwar, A., Muljono, P., \& Herawati, T. (2016). Persepsi dan partisipasi petani dalam pelaksanaan rehabilitasi tanaman kakao di Kabupaten Sigi Provinsi Sulawesi Tengah. Jurnal Penyuluhan, 12(2), $157-167$. https://doi.org/10.25015/penyuluhan.v12i2.13466

Butler, R. (1987). Task-involving and ego-involving properties of evaluation: Effects of different feedback conditions on motivational perceptions, interest, and performance. Journal of Educational Psychology, 79(4), 474-482. https://doi.org/10.1037/0022-0663.79.4.474

Fitriana, B. (2015). Pengaruh usia, pendidikan, pendapatan, faktor sosial, budaya, pribadi, dan motivasi terhadap persepsi konsumsi pangan pokok non beras di wilayah Jakarta Barat [Tugas Akhir]. UIN Syarif Hidayatullah Jakarta.

Hendayana, R. (2014). Persepsi dan Adopsi Teknologi (Nomor 10).

Herawati, N., \& Sasana, H. (2013). Analisis pengaruh pendidikan, upah pengalaman kerja, jenis kelamin dan umur terhadap produktivitas tenaga kerja industri shutllecock Kota Tegal [PhD Thesis]. Fakultas Ekonomika dan Bisnis.

Imamsyah, B., Listyowati, A. A., Hartati, P., Khoirunnisa, K., \& Seftian, W. (2019). Persepsi peternak terhadap pemberian tepung fermentasi isi rumen sebagai campuran pakan itik pedaging. Jurnal Penelitian Peternakan Terpadu, 1(1), 22-23.

Kubro, A. I., Nurlaili, \& Riyanto. (2019). Sikap peternak terhadap program kunir kabupaten Lumajang pada tahun 2019. Penyuluhan Pembangunan, 1(2), 69-77. https://doi.org/10.34145/jppm.v1i2.170

Meijer, S. S., Catacutan, D., Ajayi, O. C., Sileshi, G. W., \& Nieuwenhuis, M. (2015). The role of knowledge, attitudes and perceptions in the uptake of agricultural and agroforestry innovations among smallholder farmers in sub-Saharan Africa. International Journal of Agricultural Sustainability, 13(1), 40-54. https://doi.org/10.1080/14735903.2014.912493 
Pablo, A. L. (1994). Determinants of acquisition integration level: A decision-making perspective. Academy of management Journal, 37(4), 803-836. https://doi.org/10.5465/256601

Pusat Data dan Informasi Pertanian. (2018). Statistik Pertanian 2018. Pusat Data dan Sistem Informasi Pertanian Kementerian Pertanian Republik Indonesia.

Sappaile, B. I. (2007). Konsep instrumen penelitian pendidikan. Jurnal Pendidikan dan Kebudayaan, 13(66), 1-7. https://doi.org/10.24832/jpnk.v13i66.356

Singh, A., \& Verma, P. (2017). Factors influencing Indian consumers' actual buying behaviour towards organic food products. Journal of cleaner production, 167, 473-483. https://doi.org/10.1016/j.jclepro.2017.08.106

Sudarmono. (2007). Pedoman pemeliharaan ayam ras petelur (5 ed.). Kanisius.

Sugiyono. (2015). Metode penelitian pendidikan (hlm. 117). Alfabeta.

Suharyat, Y. (2009). Hubungan antara sikap, minat dan perilaku manusia. Jurnal Region, 1(3), 1-19.

Undang-Undang Republik Indonesia No.13 Tahun 2003 tentang Ketenagakerjaan. (2003). Lembaran Negara Republik Indonesia Tahun 2003 Nomor 391 (2003).

Wang, P., Liu, Q., \& Qi, Y. (2014). Factors influencing sustainable consumption behaviors: A survey of the rural residents in China. Journal of Cleaner Production, 63, 152-165. https://doi.org/10.1016/j.jclepro.2013.05.007

Yanti, D. N., Banuwa, I. S., Safe'i, R., Wulandari, C., \& Gumay Febryano, I. (2017). Analisis faktor-faktor yang mempengaruhi persepsi masyarakat dalam pembangunan hutan tanaman rakyat pada KPH Gedong Wani. Jurnal Hutan dan Masyarakat, 9(2), 61-77. https://doi.org/10.24259/jhm.v9i2.2861

Yusnita, S. (2010). Hubungan antara faktor-faktor sosial ekonomi dengan tingkat adopsi inovasi petani pada budidaya tanaman jeruk besar di Kecamatan Plupuh Kabupaten Sragen [Tugas Akhir]. Universitas Sebelas Maret Surakarta. 